\title{
Kerugian Keuangan Negara Dalam Pengadaan Alat Kesehatan Di Indonesia
}

\author{
Ahmad Feri Tanjung, Rizkan Zulyadi, dan Ronald Hasudungan Sianturi \\ Fakultas Hukum Universitas Prima Indonesia \\ Jln. Sekip Simpang Sikambing, Medan \\ a.feri.tanjung@gmail.com; rizkan.unpri@yahoo.com; hasudungan_r@yahoo.com
}

Received: 18 Nopember 2018; Accepted: 4 Februari 2019; Published: 24 April 2019

DOI: 10.20885/iustum.vol26.iss1.art7

\begin{abstract}
The financial loss of the state is determined by many factors leading the method of calculating the state financial loss to be unstandard and then causing uncertainty in calculation of the state financial loss, including in the procurement of medical devices. This study aims to (a) analyze the factors determining the financial loss of state in the procurement of medical devices and (b) to analyze the method used to calculate the financial loss of the state in the procurement of medical devices. This is a normative juridical research using a conceptual approach and a regulatory approach. The data used were secondary data collected through literature. From the research results, first, it can be concluded that the factors determining the fiancial loss of state in the procurement of medical devices were the factors of goods effectiveness as needed. The procurement of medical devices that has the nature of the goods is a unit to be utilized as needed, and then the method of calculating the financial loss of state used is the method of calculating the total loss, but if the medical devices that have properties can be utilized separately, the calculation of financial losses used is net loss. Another factor affecting was the price reasonableness if the procurement of medical devices can be utilized as needed but the price of medical devices exceeds the reasonableness. Second, the method of calculating financial loss of stated used due to the price reasonableness was the price reasonableness method.
\end{abstract}

Keywords: Medical devices; financial loss of state; calculation method; procurement of government goods

\begin{abstract}
Abstrak
Kerugian keuangan negara dipengaruhi oleh banyak faktor sehingga metode perhitungan kerugian keuangan negara tidak baku yang mengakibatkan ketidakpastian dalam perhitungan kerugian keuangan negara, termasuk pada pengadaan alat kesehatan. Penelitian ini bertujuan (a) untuk menganalisis faktor yang mempengaruhi kerugian keuangan negara dalam pengadaan alat kesehatan dan (b) untuk menganalisis metode yang digunakan untuk melakukan perhitungan kerugian keuangan negara dalam kegiatan pengadaan alat kesehatan. Penelitian ini merupakan penelitian yuridis normatif dengan menggunakan pendekatan konseptual dan pendekatan peraturan perundang-undangan. Data yang digunakan adalah data sekunder yang dikumpulkan melalui studi pustaka. Hasil penelitian menyimpulkan bahwa pertama, faktor yang mempengaruhi kerugian keuangan negara dalam pengadaan alat kesehatan adalah faktor kemanfataan barang sesuai kebutuhan. Pengadaan alat kesehatan yang memiliki sifat barangnya merupakan suatu kesatuan agar dapat dimanfaatkan sesuai kebutuhan, maka metode perhitungan kerugian keuangan negara yang digunakan adalah metode perhitungan total loss, namun apabila alat kesehatan yang memiliki sifat dapat dimanfaatkan secara terpisah maka perhitungan kerugian keuangan negara yang digunakan adalah metode kerugian bersih (net loss). Faktor lain yang mempengaruhi adalah faktor kewajaran harga apabila pengadaan alat kesehatan dapat dimanfaatkan sesuai kebutuhan namun harga alat kesehatan melebihi kewajaran. Kedua, metode perhitungan kerugian keuangan negara yang digunakan karena faktor kewajaran harga adalah metode kewajaran harga.
\end{abstract}

Kata-kata Kunci: Alat kesehatan; kerugian keuangan negara; metode perhitungan; pengadaan barang pemerintah 


\section{Pendahuluan}

Salah satu tujuan negara Indonesia adalah mensejahterahkan warga negara ${ }^{1}$ melalui pembangunan jiwa dan raga di mana pembangunan tersebut membutuhkan anggaran keuangan yang dirancang dan dilaksanakan melalui mekanisme Anggaran Pendapatan Belanja Negara (APBN). Anggaran belanja negara pada APBN mengalami peningkatan setiap tahun untuk sesuai kebutuhan seperti APBN 2017 yang berjumlah Rp. 2.080.500.000.000.000.000,00.² Jumlah tersebut meningkat di tahun 2018 menjadi Rp. 2.220.656.966.577.000,--3 meningkat lagi pada 2019 menjadi Rp. 2.439.687.500.000.000.000,004 . Setiap tahun, Pemerintah mengalokasikan 35\% - 40\% dari anggaran belanja untuk belanja pengadan barang/jasa pemerintah. ${ }^{5}$ Jumlah anggaran untuk pengadaan barang/jasa tersebut seharusnya dapat digunakan sesuai peraturan perundangan, namun dalam praktek kegiatan pengadaan barang/jasa masih belum sesuai peraturan perundangan sehingga mengakibatkan kerugian keuangan negara. Komisi Pemberantasan Korupsi menyatakan bahwa 50\% kasus korupsi yang ditangani KPK merupakan tindak pidana korupsi pada pengadaan barang/jasa di mana $60 \%$ kerugian keuangan negara bersumber dari kegiatan pengadaan barang/jasa. ${ }^{6}$ Kerugian keuangan negara tersebut mengakibatkan negara kehilangan kemampuan finansial untuk memberi pelayanan dan mensejahterahkan warga negaranya. Pihak yang mengakibatkan kerugian keuangan negara diwajibkan untuk mengganti kerugian keuangan negara dengan harapan negara memperoleh kemampuan finansial kembali untuk memberi pelayanan dan mensejahterahkan

1 Indonesia sebagai negara kesejahteraan tercantum pada alinea ke-4 Pembukaan UUD 1945, dengan menempatkan salah satu cita negara berupa memajukan kesejahteraan umum. Fadli Prasetyo dan Kukuh, "Politik Hukum di Bidang Ekonomi dan Pelembagaan Konsepsi Welfare State di dalam Undang-Undang Dasar 1945”, artikel dalam Jurnal Konstitusi, Vol. 9 No. 3, 2012, hlm. 495-514. Daniel Egiegba Agbiboa berpendapat bahwa korupsi merupakan faktor yang menyebabkan keterbelakangan pembangunan serta buruknya kinerja ekonomi politik. Daniel Egiegba Agbiboa, "Between Corruption and Development: The Political Economy of State Robbery in Nigeria", artikel dalam Journal of Business Ethics, Vol. 108 No. 3, 2012, hlm. 325-345.

2 Pasal 7 Undang-Undang Nomor 18 Tahun 2016 tentang Anggaran Pendapatan dan Belanja Negara Tahun Anggaran 2017, Lembaran Negara Republik Indonesia Tahun 2016, Tambahan Lebaran Negara RI Nomor 240.

3 Pasal 7 Undang-Undang Nomor 15 Tahun 2017 tentang Anggaran Pendapatan dan Belanja Negara Tahun Anggaran 2018, Lembaran Negara Republik Indonesia Tahun 2017, Tambahan Lebaran Negara RI Nomor 233.

4 Republik Indonesia, Buku II Nota Keuangan Beserta Rancangan Anggaran Pendapatan Belanja Negara Tahun Anggaran 2019, Republik Indonesia, Jakarta, 2018, hlm. II.6-3.

5 Prabowo, Agus, "Tantangan Penataan Dalam Iklim Pengadaan Barang/Jasa Pemerintah di Indonesia", Makalah pada Intenational Business Integrity Conference (IBIC) 2016, 17 November 2016, hlm. 3.

6 "Pengadaan Barang dan Jasa, Kerugian Negara 60 Persen", http://www.beritasatu.com/hukum/422190pengadaan-barang-dan-jasa-kerugian-negara-60-persen.html, diakses tanggal 23 November 2018. 
warga negaranya. ${ }^{7}$ Oleh karena itu, perhitungan kerugian keuangan negara memerlukan metode yang tepat karena berdampak pada proses penegakan hukum (baik administrasi, pidana maupun perdata) dan upaya pengembalian kerugian keuangan negara.

Secara umum terdapat 6 metode penghitungan kerugian keuangan negara yaitu:

1. Kerugian Total (Total Loss) yaitu dengan menghitung kerugian keuangan negara dengan cara seluruh jumlah yang dibayarkan dinyatakan sebagai kerugian keuangan negara. Metode penghitungan kerugian negara juga diterapkan dalam penerimaan negara yang tidak disetorkan, baik sebagian maupun seluruhnya. Bagian yang tidak disetorkan merupakan kerugian total.

2. Kerugian Total dengan Penyesuaian yaitu seperti dalam metode Kerugian Total (total loss) namun dilakukan penyesuaian ke atas sesuai situasi dan kondisi. Penyesuaian diperlukan apabila barang yang dibeli harus dimusnahkan dan pemusnahannya memakan biaya. Kerugian keuangan negara tidak hanya berupa pengeluaran untuk pengadaan barang tersebut, tetapi juga biaya yang diperlukan maupun dikeluarkan untuk memusnahkan barang tersebut.

3. Kerugian Bersih (Net Loss) yaitu seperti dalam metode kerugian total (total loss) namun dilakukan penyesuaian ke bawah. Kerugian bersih adalah kerugian total dikurangi dengan nilai bersih barang yang dianggap masih ada nilainya. Nilai bersih merupakan selisih yang bisa diperoleh dikurangi salvaging cost.

4. Harga wajar yaitu dengan menggunakan harga wajar menjadi pembanding untuk harga realisasi. Kerugian keuangan negara dimana transaksinya tidak wajar berupa selisih antara harga wajar dengan harga realisasi. Metode penghitungan kerugian keuangan negara harga wajar digunakan dalam kasus pengadaan barang maupun transaksi pelepasan dan pemanfaatan barang.

5. Biaya Kesempatan (opportunity cost). Dalam metode biaya kesempatan, apabila ada kesempatan atau peluang untuk memperoleh yang terbaik, akan tetapi justru peluang ini yang dikorbankan, maka pengorbanan ini merupakan kerugian, dalam arti opportunity cost.

6. Bunga (interest). Bunga merupakan unsur kerugian negara yang penting, terutama pada transaksi-transaksi keuangan yang seperti dalam penempatan aset. Para pelaku transaksi ini umumnya paham dengan konsep nilai waktu dari uang. Bunga perlu dimasukkan dalam penghitungan kerugian keuangan negara. Dalam sengketa perdata,

7 Ronald Hasudungan Sianturi dan Ahmad Feri Tanjung, "Implementation Imprisonment Penalty as Subsidiary of Fine Penalty: Inconsistency of State Financial Losses", artikel dalam International Journal of Environmental \& Science Education, Vol. 17 No. 7, 2017, hlm. 1635. 
kerugian bunga dihitung berdasarkan jangka waktu (periode) dan tingkat bunga yang berlaku. ${ }^{8}$

Metode perhitungan kerugian keuangan negara dapat menggunakan berbagai macam metode, baik menggunakan satu metode atau kombinasi beberapa metode, sesuai dengan jenis dan kompleksitas pekerjaan. Hal tersebut yang mengakibatkan metode penghitungan kerugian keuangan negara tidak baku yang mengakibatkan ketidakpastian dalam perhitungan kerugian keuangan negara. Tidak adanya kepastian dalam menentukan metode perhitungan kerugian keuangan negara mengakibatkan jumlah kerugian keuangan negara menjadi kontroversi karena masing-masing metode perhitungan berdampak pada hasil perhitungan yang berbeda.

Salah satu metode perhitungan kerugian keuangan negara yang tidak konsisten adalah metode perhitungan kerugian keuangan negara dalam kegiatan pengadaan barang/jasa pemerintah. Hal ini dipengaruhi kompleksitas pengadaan barang/jasa pemerintah seperti jenis pengadaan, kemanfaatan barang/jasa, metode pembayaran, jenis kontrak dan sebagainya. Sebagai contoh adalah kontroversi metode perhitungan yang digunakan apabila terdapat pekerjaan konstruksi berupa bangunan gedung yang tidak sesuai spesifikasi. Kontroversi metode perhitungan kerugian keuangan negara karena terdapat 3 metode yang dapat digunakan yaitu metode perhitungan Kerugian Total (total loss), Kerugian Total dengan penyesuaian atau atau kerugian bersih. Metode perhitungan Kerugian Total (total loss) dapat digunakan dengan pertimbangan bahwa negara seharusnya tidak melakukan pembayaran terhadap bangunan gedung yang tidak sesuai spesifikasi. Metode perhitungan Kerugian Total dengan penyesuaian dapat digunakan dengan pertimbangan bahwa negara seharusnya tidak melakukan pembayaran terhadap bangunan gedung yang tidak sesuai spesifikasi dan negara akan mengeluarkan anggaran untuk memusnahkan gedung tersebut agar dapat dibangun gedung baru. Metode perhitungan kerugian bersih (net loss) karena gedung yang tidak sesuai spesifikasi tersebut tentunya punya nilai dan kerugian

${ }^{8}$ Karel Antonius Paeh, "Pengembalian Kerugian Keuangan Negara Berdasarkan Rekomendasi Badan Pemeriksa Keuangan (BPK) Hubungan Dengan Unsur Kerugian Negara Dalam Tindak Pidana Korupsi”, artikel dalam Jurnal Kartalogis, Vol. 5 No. 2, 2017, hlm. 53-54. 
keuangan negara adalah selisih pengeluaran negara dengan nilai gedung yang tidak sesuai spesifikasi tersebut.

Salah satu sektor pengadaan adalah pengadaan barang, yaitu pengadaan benda baik berwujud maupun tidak berwujud, bergerak maupun tidak bergerak, yang dapat diperdagangkan, dipakai, dipergunakan atau dimanfaatkan oleh Pengguna Barang. Secara prinsip, negara mengeluarkan anggaran untuk melakukan pembayaran dalam kegiatan pengadaan barang pemerintah apabila negara memperoleh barang yang dapat dimanfaatkan sesuai kebutuhan dari penyedia barang. Indonesia Corruption Watch (ICW) menyatakan bahwa korupsi alat kesehatan merupakan salah satu sektor korupsi yang tinggi di Indonesia. ICW menyatakan bahwa jumlah kasus korupsi alat kesehatan selama periode 2010-2016 sebanyak 219 kasus dengan total kerugian keuangan negara mencapai Rp. 890.100.000.000.000,00. ${ }^{9}$ Pengadaan alat kesehatan dapat mengakibatkan kerugian keuangan negara apabila negara mengeluarkan anggaran yang seharusnya tidak dikeluarkan, baik yang disebabkan oleh alat kesehatan tidak dapat dimanfaatkan sesuai kebutuhan, alat kesehatan yang tidak sesuai spesifikasi atau karena jumlah pembayaran barang di luar batas kewajaran. Jumlah kerugian keuangan negara ini dipengaruhi oleh beberapa faktor sehingga berpengaruh pada metode perhitungan kerugian keuangan negara.

Pemilihan metode perhitungan berdampak pada perbedaan jumlah kerugian keuangan negara, namun hingga saat ini belum ada ketentuan yang mengatur tentang parameter/syarat untuk menggunakan metode tertentu sehingga sangat dipengaruhi oleh unsur subjektivitas dari petugas yang menghitung kerugian keuangan negara. ${ }^{10}$

\section{Rumusan Masalah}

Berdasarkan uraian pada latar belakang di atas maka dalam penelitian ini akan diuraikan rumusan permasalahan. Pertama, faktor apa yang mempengaruhi kerugian keuangan negara dalam pengadaan alat kesehatan? Kedua, metode apa

\footnotetext{
9 “Trend Korupsi Kesehatan Periode 2010 - 2015”, https://antikorupsi.org/sites/default/files/files/ Siaran\%20Pers/Tren\%20Korupsi\%20Kesehatan\%202017.pdf, diakses pada tanggal 7 Desember 2018.

10 Tuanakotta, Theodorus. M., Menghitung Kerugian Keuangan Negara dalam Tindak Pidana Korupsi, Salemba Empat, Jakarta, 2009, hlm. 144.
} 
yang digunakan untuk melakukan perhitungan kerugian keuangan negara dalam kegiatan pengadaan alat kesehatan?

\section{Tujuan Penelitian}

Adapun tujuan dari penelitian ini adalah: pertama, untuk menganalisis faktorfaktor yang mempengaruhi kerugian keuangan negara dalam pengadaan alat kesehatan. Kedua, untuk menganalisis metode yang digunakan untuk melakukan perhitungan kerugian keuangan negara dalam kegiatan pengadaan alat kesehatan.

\section{Metode Penelitian}

Penelitian ini merupakan penelitian yuridis normatif. Data yang digunakan adalah data sekunder yang meliputi bahan hukum primer dan sekunder berupa peraturan perundangan yang meliputi Undang-Undang Nomor 17 Tahun 2003 tentang Keuangan Negara, Undang-Undang Nomor 1 Tahun 2004 tentang Perbendaharaan Negara, Undang-Undang Nomor 18 Tahun 2016 tentang Anggaran Pendapatan dan Belanja Negara Tahun Anggaran 2017, UndangUndang Nomor 15 Tahun 2017 tentang Anggaran Pendapatan dan Belanja Negara Tahun Anggaran 2018 dan Peraturan Presiden Nomor 16 Tahun 2018 tentang Pengadaan Barang/Jasa Pemerintah dan putusan pengadilan terkait dengan keuangan negara dan pengadaan alat kesehatan. Data sekunder diperoleh melalui studi pustaka. Metode pendekatan yang digunakan adalah pendekatan konsep (conceptual approah) dan pendekatan peraturan perundangan (statue approach). Analisa data dilakukan dengan mensistematisasi data-data untuk selanjutnya datadata tersebut digunakan untuk menerjemahkan konsep kerugian keuangan negara serta metode perhitungan kerugian keuangan negara di sektor pengadaan barang/jasa pemerintah.

\section{Hasil Penelitian dan Pembahasan}

Faktor-Faktor yang Mempengaruhi Kerugian Keuangan Negara dalam Pengadaan Barang Pemerintah

Undang-Undang No. 17 Tahun 2003 tentang Keuangan Negara ditetapkan dan mulai berlaku sejak tanggal 5 April 2003. Pasal 1 angka 1 Undang-Undang No. 17 Tahun 2003 tentang Keuangan Negara, yang dimaksud dengan Keuangan 
Negara adalah semua hak dan kewajiban negara yang dapat dinilai dengan uang, serta segala sesuatu baik berupa uang maupun berupa barang yang dapat dijadikan milik negara berhubung dengan pelaksanaan hak dan kewajiban tersebut. Keuangan Negara sebagaimana dimaksud dalam Pasal 1 angka 1 Undang-Undang No. 17 Tahun 2003 tentang Keuangan Negara, meliputi :

1) Hak negara untuk memungut pajak, mengeluarkan dan mengedarkan uang, dan melakukan pinjaman;

2) Kewajiban negara untuk menyelenggarakan tugas layanan umum pemerintahan negara dan membayar tagihan pihak ke tiga;

3) Penerimaan negara;

4) Pengeluaran negara;

5) Penerimaan daerah;

6) Pengeluaran daerah;

7) Kekayaan negara / kekayaan daerah yang di kelola sendiri atau oleh pihak lain berupa uang, surat berharga, piutang barang serta hak-hak lain yang dapat dinilai dengan uang, termasuk kekayaan yang dipisahkan pada perusahaan negara/perusahaan daerah;

8) Kekayaan pihak lain yang dikuasai oleh pemerintah dalam rangka penyelenggaraan tugas pemerintahan dan/ atau kepentingan umum;

9) Kekayaan pihak lain yang diperoleh dengan menggunakan fasilitas yang diberikan pemerintah ${ }^{11}$;

Kekuasaan pengelolaan keuangan negara berada ditangan presiden selaku kepala pemerintahan sebagai bagian dari kekuasaan pemerintahan. Dalam pelaksanaanya pengelolaan keuangan negara dapat dikuasakan oleh presiden kepada (a) Menteri Keuangan, selaku pengelola fiskal dan wakil pemerintah dalam kepemilikan kekayaan negara yang dipisahkan; (b) menteri/pimpinan lembaga selaku Pengguna Anggaran/Pengguna Barang kementerian negara/lembaga yang dipimpinnya dan (c) Kepala Daerah yaitu gubernur/bupati/walikota selaku kepala pemerintahan daerah untuk mengelola keuangan daerah dan mewakili pemerintah daerah dalam kepemilikan kekayaan daerah yang dipisahkan. Kekuasaan pengelolaan Keuangan Negara meliputi kewenangan yang bersifat umum dan kewenangan yang bersifat khusus. Kewenangan yang bersifat umum meliputi penetapan arah, kebijakan umum, strategi, dan prioritas dalam pengelolaan $\mathrm{APBN}$, antara lain penetapan pedoman pelaksanaan dan

${ }^{11}$ Kekayaan pihak lain meliputi kekayaan yang dikelola oleh orang atau badan lain berdasarkan kebijakan pemerintah, yayasan-yayasan di lingkungan kementerian negara/lembaga, atau perusahaan negara/daerah. 
pertanggungjawaban $\mathrm{APBN}$, penetapan pedoman penyusunan rencana kerja kementerian negara/lembaga, penetapan gaji dan tunjangan, serta pedoman pengelolaan Penerimaan Negara. Sedangkan kewenangan yang bersifat khusus meliputi keputusan/kebijakan teknis yang berkaitan dengan pengelolaan APBN, antara lain keputusan sidang kabinet di bidang pengelolaan APBN, keputusan rincian $\mathrm{APBN}$, keputusan dana perimbangan, dan penghapusan aset dan piutang negara.

Keuangan negara tersebut harus dilihat secara holistik baik dari sisi subjek, objek, proses dan tujuan. Dari sisi subjek berkaitan dengan pihak yang melakukan pengelolaan keuangan negara. Pendekatan dari sisi obyek menyatakan bahwa yang dimaksud dengan keuangan negara meliputi semua hak dan kewajiban negara yang dapat dinilai dengan uang, termasuk kebijakan dan kegiatan dalam bidang fiskal, moneter dan pengelolaan kekayaan negara yang dipisahkan, serta segala sesuatu baik berupa uang, maupun berupa barang yang dapat dijadikan milik negara berhubung dengan pelaksanaan hak dan kewajiban tersebut. Pendekatan dari sisi subyek dinyatakan yang dimaksud dengan keuangan negara meliputi seluruh obyek sebagaimana tersebut di atas yang dimiliki negara, dan/atau dikuasai oleh pemerintah pusat, pemerintah daerah, perusahaan negara/daerah, dan badan lain yang ada kaitannya dengan keuangan negara. Pendekatan dari sisi proses mencakup seluruh rangkaian kegiatan yang berkaitan dengan pengelolaan obyek sebagaimana tersebut di atas mulai dari perumusan kebijakan dan pengambilan keputusan sampai dengan pertanggunggjawaban. Pendekatan dari sisi tujuan, keuangan negara meliputi seluruh kebijakan, kegiatan dan hubungan hukum yang berkaitan dengan pemilikan dan/atau penguasaan obyek sebagaimana tersebut di atas dalam rangka penyelenggaraan pemerintahan negara.

Pengelolaan keuangan negara tidak akan lepas dari kerugian keuangan negara. Undang-Undang Nomor 17 Tahun 2003 tidak dijelaskan defenisi kerugian keuangan negara, namun hanya mengamanatkan pengaturan lebih lanjut tentang penyelesaian kerugian keuangan negara dalam Undang-Undang Nomor 1 Tahun 
2004 tentang Pembendaharaan Negara. ${ }^{12}$ Hal tersebut menimbulkan 2 pandangan perhitungan kerugian keuangan negara yaitu actual lose dan potential lose. Pandangan actual loss berpendapat bahwa penghitungan kerugian keuangan negara harus sama persis dengan jumlah kekayaan atau keuntungan yang diperoleh pelaku, sedangkan pandangan potential lose berpendapat bahwa penghitungan kerugian keuangan negara tidak harus sama persis dengan jumlah kekayaan atau keuntungan yang diperoleh pelaku. ${ }^{13}$

Kegiatan pengadaan barang/jasa adalah kegiatan Pengadaan Barang/Jasa oleh Kementerian/Lembaga/Perangkat Daerah yang dibiayai oleh APBN/APBD yang prosesnya sejak identifikasi kebutuhan, sampai dengan serah terima hasil pekerjaan. ${ }^{14}$ Peraturan dan prosedur yang digunakan dalam pengadaan barang/jasa pemerintah adalah merupakan upaya untuk memastikan bahwa output barang/jasa tersebut diperoleh dengan cara yang kompetitif dan transparan untuk mendapatkan harga terbaik (menguntungkan secara ekonomi).15 Pengembangan peraturan dan prosedur pengadaan barang/jasa pemerintah merupakan bagian penting untuk membangun pemerintahan yang bersih dan berwibawa. ${ }^{16}$

Kegiatan pengadaan barang/jasa pemerintah merupakan kewenangan presiden selaku pengelolaan keuangan negara yang didelegasikan kepada Pengguna Anggaran untuk menggunakan anggaran untuk kegiatan pengadaan barang/jasa pemerintah sesuai Peraturan Presiden No. 16 Tahun 2018 tentang Pengadaan Barang/Jasa Pemerintah. Dalam melaksanakan kegiatan pengadaan barang/jasa tersebut, Pengguna Anggaran diwajibkan untuk membentuk dan mendelegasikan kewenangan kepada organisasi pengadaan yang terdiri dari Kuasa Pengguna Anggaran (KPA), Pejabat Pengadaan/Pokja Pemilihan, Pejabat

12 A.P. Edi Atmadja, "Penyelesaian Kerugian Daerah Melalui Penyetoran Ke Kas Negara: Suatu Kajian Hukum Doktrinal”, artikel dalam Jurnal Tata Kelola \& Akuntabilitas Kenangan Negara, Vol. 3 No. 2, 2017, hlm. 172.

${ }_{13}$ Mahrus Ali, "Hubungan Antara Sumber dan Metode Penghitungan Kerugian Keuangan Negara dengan Penetapan Uang Pengganti”, artikel dalam Jurnal Ius Quia Iustum, No. 1 Vol. 21, 2014, hlm. 44.

14 Pasal 1 butir 1 Peraturan Presiden Nomor 16 Tahun 2018 Tentang Pengadaan Barang/Jasa Pemerintah, Lembaran Negara Republik Indonesia Tahun 2018, Tambahan Lebaran Negara RI Nomor 33.

15 Direktorat Penelitian dan Pengembangan Komisi Pemberantasan Korupsi (KPK) Republik Indonesia, Kajian Pencegahan Korupsi Pada Pengadaan Barang dan Jasa Pemerintah, Kajian, Komisi Pemberantasan Korupsi (KPK) Republik Indonesia, Jakarta, 2014, hlm. 15.

16 Apri Listiyanto, "Pembaharuan Regulasi Pengadaan Barang dan Jasa Pemerintah", artikel dalam Jurnal Rechts Vinding, Vol. 1 No. 1, 2012, hlm. 115. 
Pembuat Komitmen (PPK), dan Pejabat/Panitia Pemeriksa Hasil Pekerjaan (PPHP). Masing-masing organisasi pengadaan tersebut memiliki tugas dan kewenangan yang berbeda namun merupakan suatu rangkaian dalam proses pengadaan barang/jasa, yaitu (a) KPA memiliki tugas dan kewenangan berdasarkan kewenangan dari Pengguna Anggaran17, (b) Pejabat Pengadaan/Pokja Pemilihan memiliki tugas dan kewenangan berkaitan dengan pemilihan penyedia18; (c) PPK memiliki tugas dan kewenangan berkaitan dengan pelaksanaan kontrak ${ }^{19}$; (d) PPHP memiliki tugas dan kewenangan berkaitan dengan pemeriksaan administrasi hasil pekerjaan. ${ }^{20}$ Masing-masing organisasi pengadaan tersebut melaksanakan tugas dan kewenangannya dengan memperhatikan prinsip-prinsip dan etika pengadaan.

Penggunaan keuangan negara tersebut dilakukan oleh Pengguna Anggaran berdasarkan kontrak dengan pihak penyedia barang/jasa. Kontrak antara Pengguna Anggaran mengacu pada Peraturan Presiden Nomor 16 Tahun 2018 tentang Pengadaan Barang/Jasa Pemerintah dimana jenis kontrak dalam pengadaan barang/jasa pemerintah yaitu:

1).Kontrak Lumsum yaitu merupakan kontrak dengan ruang lingkup pekerjaan dan jumlah harga yang pasti dan tetap dalam batas waktu tertentu dengan ketentuan semua risiko sepenuhnya ditanggung oleh Penyedia, berorientasi kepada keluaran dan pembayaran didasarkan pada tahapan produk/keluaran yang dihasilkan sesuai dengan Kontrak.

2). Kontrak Harga Satuan merupakan kontrak Pengadaan Barang/Pekerjaan Konstruksi/Jasa Lainnya dengan harga satuan yang tetap untuk setiap satuan atau unsur pekerjaan dengan spesifikasi teknis tertentu atas penyelesaian seluruh pekerjaan dalam batas waktu yang telah ditetapkan dengan ketentuan volume atau kuantitas pekerjaannya masih bersifat perkiraan pada saat Kontrak ditandatangani, pembayaran berdasarkan hasil pengukuran bersama atas realisasi volume pekerjaan, nilai akhir kontrak ditetapkan setelah seluruh pekerjaan diselesaikan.

3). Kontrak Gabungan Lumsum dan Harga Satuan merupakan Kontrak Pengadaan Barang/Pekerjaan Konstruksi/Jasa Lainnya gabungan Lumsum dan Harga Satuan dalam 1 (satu) pekerjaan yang diperjanjikan.

17 Pasal 10 Peraturan Presiden Nomor 16 Tahun 2018 tentang Pengadaan Barang/Jasa Pemerintah, Lembaran Negara Republik Indonesia Tahun 2018, Tambahan Lebaran Negara RI Nomor 33.

18 Pasal 12 dan Pasal 13 Peraturan Presiden Nomor 16 Tahun 2018 tentang Pengadaan Barang/Jasa Pemerintah, Lembaran Negara Republik Indonesia Tahun 2018, Tambahan Lebaran Negara RI Nomor 33.

19 Pasal 11 Peraturan Presiden Nomor 16 Tahun 2018 tentang Pengadaan Barang/Jasa Pemerintah, Lembaran Negara Republik Indonesia Tahun 2018, Tambahan Lebaran Negara RI Nomor 33.

20 Pasal 15 Peraturan Presiden Nomor 16 Tahun 2018 tentang Pengadaan Barang/Jasa Pemerintah, Lembaran Negara Republik Indonesia Tahun 2018, Tambahan Lebaran Negara RI Nomor 33. 
4). Kontrak Terima Jadi (Turnkey) merupakan Kontrak Pengadaan Pekerjaan Konstruksi atas penyelesaian seluruh pekerjaan dalam batas waktu tertentu dengan ketentuan jumlah harga pasti dan tetap sampai seluruh pekerjaan selesai dilaksanakan dan pembayaran dapat dilakukan berdasarkan termin sesuai kesepakatan dalam Kontrak.

5). Kontrak Payung sebagaimana dapat berupa kontrak harga satuan dalam periode waktu tertentu untuk barang/jasa yang belum dapat ditentukan volume dan/atau waktu pengirimannya pada saat Kontrak ditandatangani.

6). Kontrak berdasarkan Waktu Penugasan merupakan Kontrak Jasa Konsultansi untuk pekerjaan yang ruang lingkupnya belum bisa didefinisikan dengan rinci dan/atau waktu yang dibutuhkan untuk menyelesaikan pekerjaan belum bisa dipastikan. ${ }^{21}$

Undang-Undang No. 17 Tahun 2003 tentang Keuangan Negara tidak terlepas dengan Undang-Undang No. 1 Tahun 2004 tentang Perbendaharaan Negara yang mengatur tentang pengelolaan dan pertanggungjawaban keuangan negara, termasuk investasi dan kekayaan yang dipisahkan, yang ditetapkan dalam APBN dan APBD. 22 Pengguna Anggaran diwajibkan untuk mengikuti prinsip-prinsip tata kelola pemerintahan (good corporate governance) dalam menggunakan anggaran untuk belanja, termasuk untuk kegiatan pengadaan barang/jasa pemerintah, agar terhindar dari kerugian keuangan negara. Kerugian keuangan negara dapat terjadi apabila terjadi kekurangan uang, surat berharga, dan barang, yang nyata dan pasti jumlahnya sebagai akibat perbuatan melawan hukum baik sengaja maupun lalai. ${ }^{23}$

Tuanakotta berpendapat bahwa terdapat empat cabang yang bisa menjadi sumber dari kerugian keuangan negara yaitu aset (asset), kewajiban (liability), penerimaan (revenue) dan pengeluaran (expenditure). ${ }^{24}$ Apabila dikaitkan dengan kegiatan pengadaan barang/jasa maka kerugian keuangan negara juga dapat empat cabang yaitu:

21 Jenis kontrak yang digunakan sesuai dengan jenis pengadaan yaitu pengadaan barang, pekerjaan konstruksi dan jasa lainnya dapat menggunakan jenis kontrak Lumsum, Harga Satuan, Gabungan Lumsum dan Harga Satuan, Terima Jadi (Turnkey) dan Kontrak Payung; sedangkan pengadaan jasa konsultansi dapat menggunakan jenis kontrak Lumsum, Waktu Penugasan dan Kontrak Payung. Pasal 27 Peraturan Presiden Nomor 16 Tahun 2018 Tentang Pengadaan Barang/Jasa Pemerintah, Lembaran Negara Republik Indonesia Tahun 2018, Tambahan Lebaran Negara RI Nomor 33.

22 Pasal 1 butir 1 Undang-Undang Nomor 1 Tahun 2004 tentang Perbendaharaan Negara, Lembaran Negara Republik Indonesia Tahun 2004, Tambahan Lebaran Negara RI Nomor 5.

23 Pasal 1 butir 22 Undang-Undang Nomor 1 Tahun 2004 tentang Perbendaharaan Negara, Lembaran Negara Republik Indonesia Tahun 2004, Tambahan Lebaran Negara RI Nomor 5.

24 Tuanakotta, Theodorus. M., Menghitung Kerugian Keuangan Negara dalam Tindak Pidana Korupsi, Salemba Empat, Jakarta, 2009, hlm. 144. 
1). Kerugian keuangan negara pada cabang aset yang berkaitan dengan pengadaan aset, pelepasan aset, pemanfaatan aset, penempatan aset dan kredit macet. Apabila dikaitkan dengan kegiatan pengadaan barang/jasa pemerintah maka kerugian keuangan negara dapat terjadi apabila negara memperoleh aset berupa barang atau jasa yang tidak sesuai dengan kontrak, baik dari segi kualitas maupun kuantitas. Selain itu, pengadaan barang/jasa yang tidak sesuai dengan kebutuhan sehingga barang/jasa tidak dapat dimanfaatkan merupakan bentuk lain dari kerugian keuangan negara yang berkaitan dengan faktor asset.

2). Kerugian keuangan negara pada cabang kewajiban (liability) dapat dikelompokan menjadi 3 jenis yaitu perikatan yang menimbulkan kewajiban nyata, kewajiban bersyarat yang menjadi nyata, dan kewajiban tersembunyi yang menjadi nyata. Apabila dikaitkan dengan pengadaan barang/jasa maka kerugian keuangan negara juga dapat berasal dari kewajiban yang harus dibayarkan oleh negara karena pelanggaran peraturan perundangan atau pelanggaran kontrak yang dilakukan oleh pihak pemilik pekerjaan.

3). Kerugian keuangan negara pada cabang penerimaan dapat berupa wajib bayar tidak melaksanakan pembayaran kepada negara, penerimaan negara tidak disetor secara utuh oleh pejabat yang bertanggung jawab dan penyimpangan diskresi yang dimiliki oleh pejabat tertentu yang mengakibatkan kerugian keuangan negara. Apabila dikaitkan dengan kegiatan pengadaan barang/jasa pemerintah maka kerugian keuangan negara pada faktor penerimaan dapat berupa penyedia tidak melakukan pembayaran denda sesuai ketentuan atau penyimpangan kewenangan oleh pihak pemilik pekerjaan karena tidak mengenakan denda kepada pihak penyedia sesuai peraturan perundangan dan kontrak. Dalam hal ini, pihak pemilik pekerjaan tidak memiliki kewenangan untuk memberikan diskresi berupa pengurangan denda kepada penyedia karena besar denda telah diatur dalam peraturan perundangan dan kontrak sehingga pihak pemilik pekerjaan tidak memiliki kewenangan untuk memberikan diskresi tersebut.

4). Kerugian keuangan negara terjadi karena cabang pengeluaran negara dilakukan lebih dari seharusnya, atau pengeluaran negara seharusnya tidak dilakukan, dan/atau pengeluaran negara dilakukan lebih cepat. Apabila dikaitkan dengan kegiatan pengadaan barang/jasa pemerintah maka kerugian keuangan negara pada cabang pengeluaran seperti pembayaran kepada penyedia dimana pekerjaan yang fiktif, pekerjaan yang tidak sesuai kualitas dan kuantitas, dan pekerjaan yang belum selesai.

Penggunaan keuangan negara dalam kegiatan pengadan barang/jasa diharapkan mencapai tujuan pengadaan yaitu menghasilkan barang/jasa yang tepat dari setiap uang yang dibelanjakan, diukur dari aspek kualitas, jumlah, waktu, biaya, lokasi, dan Penyedia. Namun, apabila pengeluaran anggaran yang merupakan bagian dari keuangan negara tersebut tidak menghasilkan barang/jasa 
yang dapat dimanfaatkan sesuai kebutuhan, maka negara mengalami kerugian keuangan negara.

Pembayaran yang dilakukan oleh Pemilik Pekerjaan (Pengguna Anggaran) hanya dapat dilakukan sesuai dengan prestasi pekerjaan Penyedia dengan memperhatikan kontrak pengadaan barang/jasa. Apabila terjadi pembayaran yang melebihi prestasi pekerjaan atau tidak sesuai dengan kontrak pengadaan barang/jasa maka hal tersebut telah menimbulkan kerugian keuangan negara karena pembayaran tersebut tidak seharusnya dilakukan oleh Pengguna Anggaran (Pemilik Pekerjaan). Metode perhitungan kerugian keuangan negara dalam kegiatan pengadaan barang/jasa pemerintah dilakukan dengan memperhatikan karateristik pengadaan barang/jasa pemerintah dengan memperhatikan faktorfaktor sebagai berikut:

\section{Faktor Kemanfaatan Barang}

Sesuai dengan prinsip pengeluaran anggaran pada pengadaan barang/jasa bahwa anggaran negara dikeluarkan agar barang yang diperoleh dapat dimanfaatkan sesuai kebutuhan maka kemanfaatan barang dapat dikategorikan menjadi 2 (dua) kelompok pengadaan barang yaitu (a) barang yang sifat barangnya merupakan suatu kesatuan agar dapat dimanfaatkan sesuai kebutuhan dan (b) barang yang sifat barangnya dapat dimanfaatkan secara terpisah.

\section{a. Pengadaan Barang Yang Sifat Barangnya Merupakan Suatu Kesatuan Agar Dapat Dimanfaatkan}

Salah satu contoh pengadaan barang yang sifat barangnya merupakan suatu kesatuan agar dapat dimanfaatkan sesuai kebutuhan adalah pengadaan instalasi peralatan kedokteran yang terdiri dari barang berupa komputer, program komputer, instalasi computer dan sebagainya yang merupakan suatu kesatuan agar dapat dimanfaatkan sesuai kebutuhan. Apabila sebagian barang tidak ada atau tidak sesuai spesifikasi maka sistem informasi tersebut tidak dapat dimanfaatkan sesuai dengan kebutuhan.

Jenis pembayaran yang dapat digunakan dalam pengadaan ini adalah pembayaran lumsum setelah penyedia menyelesaikan pekerjaan. Jenis pembayaran lumsum karena pembayaran dilakukan apabila barang dapat dimanfaatkan sesuai dengan kebutuhan, dalam hal ini barang dapat 
dimanfaatkan apabila Penyedia telah menyelesaikan pekerjaannya. Pengguna Anggaran tidak dapat melakukan pembayaran apabila Penyedia belum menyelesaikan seluruh pekerjaannya. Pembayaran yang dilakukan sebelum Penyedia menyelesaikan seluruh pekerjaannya merupakan kerugian keuangan negara karena pembayaran tersebut seharusnya tidak dilakukan oleh Pengguna Anggaran. Apabila barang tersebut tidak dapat berfungsi, baik karena belum seluruh komponen tersedia maupun karena alasan lainnya, maka seluruh pembayaran yang dilakukan Pengguna Anggaran merupakan kerugian keuangan negara.

Dalam praktik, pengadaan barang yang sifatnya suatu kesatuan tersebut dapat menggunakan metode pembayaran berdasarkan tahapan penyelesaian pekerjaan/termin. Hal tersebut menjadi sengketa terkait dengan keabsahan pembayaran sesuai termin apabila dilakukan pembayaran sesuai termin namun pada akhirnya barang tidak dapat dimanfaatkan sesuai dengan kebutuhan. Apabila hal tersebut terjadi, maka pembayaran tahapan penyelesaian pekerjaan/termin tersebut adalah sah karena dilakukan berdasarkan kontrak, namun kerugian keuangan negara juga terjadi karena barang tidak dapat dimanfaatkan sesuai kebutuhan.

Salah satu perhitungan kerugian keuangan negara dalam tindak pidana korupsi pengadaan alat kesehatan yang sifat barangnya merupakan satu kesatuan agar dapat dimanfaatkan adalah Pengadaan Cathlab pada Rumah Sakit Stroke Nasional (RSSN) Bukit Tinggi Tahun Anggaran 2012. Alat kesehatan berupa 1 unit Cathlab, 1 unit UPS, 1 paket pekerjaan ruangan cathlab dan 1 paket installation dengan total kontrak Rp. 16.805.000.000,00 merupakan suatu kesatuan agar dapat dimanfaatkan sesuai kebutuhan. Dalam perkara ini, Pihak dari RSSN Bukit Tinggi telah melakukan serah terima alat kesehatan dan melakukan pembayaran $100 \%$ walaupun peralatan belum dilakukan uji fungsi. Dalam perkembangannya, peralatan cathlab tersebut tidak dapat dimanfaatkan sesuai kebutuhan karena tidak lolos uji fungsi sehingga seharusnya Pihak RSSN 
Bukit Tinggi tidak melakukan pembayaran sehingga total kerugian adalah Rp. $16.805 .000 .000,00 .^{25}$

\section{b. Barang yang Sifat Kemanfaatan Barangnya Dapat Dimanfaatkan Secara Terpisah}

Pengadaan alat kesehatan yang sifat barangnya dapat dimanfaatkan secara terpisah adalah alat-alat kesehatan dimana masing-masing alat kesehatan dapat dimanfaatkan secara terpisah. Apabila penyedia tidak melaksanakan pekerjaannya secara sempurna, baik karena alat kesehatan tidak sesuai kuantitas dan atau tidak sesuai kualitas karena tidak sesuai spesifikasi, maka sebahagian alat kesehatan yang lain yang sesuai spesifikasi masih dapat dimanfaatkan sesuai kebutuhan.

Pembayaran untuk pengadaan alat kesehatan yang sifatnya dapat dimanfaatkan secara terpisah adalah pembayaran berdasarkan tahapan penyelesaian pekerjaan/termin. Pembayaran hanya dapat dilakukan apabilan Penyedia telah melaksanakan pekerjaan sesuai dengan termin. Apabila Pemilik Pekerjaan melakukan pembayaran melebihi dari tahapan penyelesaian pekerjaan/termin maka kerugian keuangan negara sebesar kelebihan pembayaran yang seharusnya tidak dibayarkan oleh Pengguna Anggaran. ${ }^{26}$ Sebagai contoh adalah pengadaan barang berupa alat kesehatan sebanyak 100 unit dimana apabila pekerjaan penyedia hanya 50 unit alat kesehatan namun dilakukan pembayaran sebanyak 70 unit alat kesehatan maka kerugian keuangan negara adalah senilai 20 unit alat kesehatan yang seharusnya tidak dibayarkan.

Pembayaran untuk pengadaan barang yang sifatnya dapat dimanfaatkan secara terpisah juga dapat menggunakan pembayaran secara lumsum. Dalam hal ini, Pengguna Anggaran hanya dapat melakukan pembayaran apabila seluruh pekerjaan Penyedia telah selesai dan barang dapat dimanfaatkan sesuai kebutuhan. Apabila Pengguna Anggaran melakukan pembayaran sebelum

25 Putusan Mahkamah Agung Republik Indonesia No. 363 K/PID.SUS/2016 mengenai Pengadaan Cathlab pada Rumah Sakit Stroke Nasional (RSSN) Bukit Tinggi Tahun Anggaran 2012 dengan terdakwa H. Mawardi.

${ }^{26}$ Kelebihan pembayaran dapat diakibatkan dari perbuatan melawan hukum dalam wilayah hukum perdata atau wilayah hukum publik. Siti Anisah, Trisno Raharjo, "Batasan Melawan Hukum dalam Perdata dan Pidana Pada Kasus Persekongkolan Tender”, artikel dalam Jurnal Ius Quia Iustum, Vol. 25 No. 1, 2018, hlm. 44. 
Penyedia menyelesaikan pekerjaan sesuai termin maka pembayaran tersebut merupakan kerugian keuangan negara karena pembayaran tersebut tidak seharusnya dilakukan oleh Pengguna Anggaran.

Salah satu perhitungan kerugian keuangan negara dalam tindak pidana korupsi pengadaan alat kesehatan yang sifat barangnya dapat dimanfaatkan secara terpisah adalah korupsi pada pengadaan 17 jenis alat kesehatan pada Rumah Sakit Cibabat Kota Cimahi yang bersumber dari Bantuan APBD Propinsi Jawa Barat Tahun Anggaran 2011 dengan terdakwa dr. Endang Kesuma Wardani yang merupakan Direktur Utama Rumah Sakit Cibabat Kota Cimahi sebagai Pengguna Anggaran. Dalam proses pengadaan tersebut, Terdakwa melakukan pembayaran sebesar Rp. 8.300.000.000,00 kepada penyedia dimana sebahagian alat kesehatan telah sesuai dengan spesifikasi dan sebahagian alat kesehatan tidak sesuai spesifikasi. Dalam hal ini, kerugian keuangan negara terjadi karena Rumah Sakit Cibabat Kota Cimahi juga melakukan pembayaran terhadap sebahagian alat kesehatan yang tidak sesuai spesifikasi sehingga jumlah kerugian dari alat kesehatan yang tidak sesuai spesifikasi tersebut adalah Rp. 3.133.000.000.000,00. ${ }^{27}$

\section{Faktor Kewajaran Harga Barang}

Cabang kerugian keuangan negara adalah pengeluaran yang dapat terjadi karena faktor kewajaran harga pada kontrak pengadaan barang/jasa dimana Pengguna Anggaran melakukan pembayaran terhadap barang sesuai harga pada kontrak pengadaan barang/jasa yang harganya tidak wajar karena lebih mahal dari harga pasar.

Dalam proses pengadaan barang/jasa pemerintah, harga pada kontrak pengadaan barang/jasa pemerintah telah mengalami tahapan seperti:

a) Tahap Persiapan Pemilihan Penyedia Barang/Jasa. Pada tahap persiapan pemilihan barang/jasa, PPK menyusun dan menetapkan Harga Perkiraan Sendiri (HPS) untuk suatu kegiatan pengadaan barang/jasa pemerintah. HPS

27 Putusan Pengadilan Negeri Bandung No. 67/Pid.Sus-TPK/2016/PN.Bdg mengenai Perkara Tindak Pidana Korupsi Pengadaan pengadaan 17 (tujuh belas) jenis alat kesehatan pada Rumah Sakit Cibabat Kota Cimahi yang bersumber dari Bantuan APBD Propinsi Jawa Barat Tahun Anggaran 2011 dengan terdakwa dr. Endang Kesuma Wardani. 
dihitung secara keahlian dan menggunakan data yang dapat dipertanggungjawabkan untuk memperoleh harga pasar yang wajar. HPS tersebut berfungsi sebagai alat untuk menilai kewajaran harga penawaran dan dasar untuk menetapkan batas tertinggi penawaran yang sah. ${ }^{28}$

b) Tahap Pelaksanaan Pemilihan Penyedia Barang/Jasa. Pada tahap ini, Penyedia mengajukan penawaran dimana harga penawaran tidak boleh lebih tinggi dari HPS. Selanjutnya Pejabat Pengadaan/Pokja Pemilihan melakukan evaluasi terhadap penawaran sehingga diperoleh pemenang tender dengan harga penawaran yang digunakan sebagai nilai kontrak pengadaan barang/jasa pemerintah.

Harga barang sesuai kontrak pengadaan barang/jasa pemerintah seharusnya tidak lebih tinggi dari harga pasar yang wajar. Apabila pengadaan barang/jasa telah dilakukan sesuai dengan prinsip dan etika pengadaan maka seharusnya nilai kontrak pengadaan barang sesuai dengan harga pasar. Dalam hal pengadaan barang telah sesuai spesifikasi dan dapat dimanfaatkan sesuai dengan kebutuhan namun nilai kontrak di atas harga yang wajar maka terjadi kerugian keuangan negara karena negara melakukan pembayaran lebih besar daripada yang sewajarnya dibayar.

Salah satu perhitungan kerugian keuangan negara dalam tindak pidana korupsi pengadaan alat kesehatan karena faktor kewajaran harga adalah korupsi pada Pengadaan Barang/Jasa program peningkatan pelayanan kesehatan pengungsi korban bencana dan penanggulangan masalah kesehatan pada pusat penanggulangan masalah kesehatan 2005 dengan terdakwa Siti Fadilah Supari. Dalam proses pengadaan alat kesehatan tersebut, terdakwa memberikan rekomendasi kepada PPK untuk melakukan penunjukan langsung PT. Indofarma Tbk. sebagai penyedia. Penunjukan langsung tersebut bertentangan dengan prosedur pengadaan barang/jasa karena pengadaan tersebut merupakan pengadaan untuk buffer stock (persediaan barang) sehingga tidak termasuk kategori

${ }^{28}$ Pasal 25 ayat (5) Peraturan Presiden No. 16 Tahun 2018 tentang Pengadaan Barang/Jasa Pemerintah menyatakan bahwa "HPS digunakan sebagai: a. alat untuk menilai kewajaran harga penawaran dan/atau kewajaran harga satuan; b. dasar untuk menetapkan batas tertinggi penawaran yang sah dalam Pengadaan Barang/Pekerjaan Konstruksi/Jasa Lainnya; dan c. dasar untuk menetapkan besaran nilai Jaminan Pelaksanaan bagi penawaran yang nilainya lebih rendah $80 \%$ (delapan puluh persen) dari nilai HPS." 
force majeure (keadaaan kahar) yang menjadi salah satu syarat untuk penunjukan langsung. Kerugian keuangan negara terjadi karena faktor kewajaran harga dimana PPK tidak menyusun HPS secara keahlian dan menggunakan data yang dapat dipertanggungjawabkan untuk memperoleh harga pasar yang wajar, tetapi PPK menggunakan HPS dari calon penyedia yaitu PT. Indofarma Tbk. sebesar Rp. 15.548.280.000,00. Harga barang tersebut tidak wajar karena PT. Indofarma Tbk. memperoleh barang dari PT. Mitra Medidua seharga Rp. 12.325.545.000,00 dan PT. Mitra Medidua memperoleh harga dari PT. Bineka Usaha Raya seharga Rp. 7.774.140.000,00. Dengan demikian, harga pasar yang wajar untuk alat kesehatan tersebut adalah Rp. 7.774.140.000,00 namun jumlah yang dibayarkan sesuai kontrak adalah Rp. 15.548.280.000,00 sehingga Badan Pemeriksa Keuangan menyatakan selisih Rp. 6.148.638.000,00 merupakan kerugian keuangan negara. ${ }^{29}$

\section{Metode yang Digunakan Untuk Melakukan Perhitungan Kerugian Keuangan Negara dalam Kegiatan Pengadaan Barang Pemerintah}

Faktor kemanfaatan barang dan faktor kewajaran harga barang dalam kegiatan pengadaan barang Pemerintah merupakan faktor yang mempengaruhi kerugian keuangan negara cabang pengeluaran. Faktor kemanfaatan barang akan berdampak pada kerugian keuangan negara apabila barang tidak dapat dimanfaatkan sesuai kebutuhan karena negara seharusnya tidak mengeluarkan anggaran untuk barang yang tidak dapat dimanfaatkan sesuai kebutuhan. Apabila pengadaan dilakukan untuk barang yang sifatnya merupakan suatu kesatuan agar dapat dimanfaatkan sesuai kebutuhan namun barang tersebut tidak dapat dimanfaatkan sesuai kebutuhan maka metode perhitungan kerugian keuangan negara yang digunakan adalah metode kerugian total (total loss) karena setiap pengeluaran negara terhadap barang tersebut merupakan kerugian keuangan negara. Metode kerugian total (total loss) digunakan pada perkara tindak pidana korupsi Pengadaan Cathlab pada Rumah Sakit Stroke Nasional (RSSN) Bukit Tinggi Tahun Anggaran 2012 karena cathlab tersebut tidak dapat dimanfaatkan

${ }_{29}$ Putusan Pengadilan Negeri Jakarta Pusat No. 30/PID.SUS/TPK/2017/PNJKT.PST mengenai perkara tindak pidana korupsi pengadaan program peningkatan pelayanan kesehatan pengungsi korban bencana dan penanggulangan masalah kesehatan pada pusat penanggulangan masalah kesehatan Tahun 2005 dengan terdakwa Siti Fadilah Supari. 
sesuai kebutuhan sehingga seharusnya Rumah Sakit Stroke Nasional (RSSN) Bukit Tinggi tidak melakukan pembayaran kepada Penyedia.

Apabila pengadaan dilakukan terhadap barang yang sifat barangnya dapat dimanfaatkan secara terpisah dimana negara sudah mengeluarkan anggaran namun hanya sebahagian barang yang dapat dimanfaatkan sesuai kebutuhan maka kerugian keuangan negara berupa barang yang tidak dapat dimanfaatkan sesuai kebutuhan sehingga metode perhitungan kerugian keuangan negara yang digunakan adalah metode kerugian bersih (net loss). Perhitungan dengan metode kerugian bersih (net loss) digunakan pada pengadaan 17 jenis alat kesehatan pada Rumah Sakit Cibabat Kota Cimahi karena sebahagian barang dapat dimanfaatkan sesuai kebutuhan namun sebahagian barang tidak dapat dimanfaatkan sesuai kebutuhan sehingga pembayaran yang dilakukan terhadap alat kesehatan yang tidak dapat dimanfaatkan sesuai kebutuhan merupakan kerugian keuangan negara.

Pengadaan barang yang dapat dimanfaatkan sesuai dengan kebutuhan juga dapat mengakibatkan kerugian keuangan negara apabila harga barang tersebut tidak wajar karena lebih tinggi dari harga pasar yang wajar. Kerugian keuangan negara timbul karena negara mengeluarkan anggaran lebih tinggi daripada anggaran yang seharusnya dikeluarkan. Oleh karena itu, metode perhitungan kerugian keuangan negara yang digunakan adalah metode harga wajar yaitu dengan menggunakan harga wajar menjadi pembanding untuk harga realisasi. Metode perhitungan harga wajar digunakan pada pengadaan alat kesehatan pada program peningkatan pelayanan kesehatan pengungsi korban bencana dan penanggulangan masalah kesehatan pada pusat penanggulangan masalah kesehatan 2005 dimana harga alat kesehatan yang wajar senilai Rp. 15.548.280.000,00 namun dibayarkan sebesar Rp. 15.548.280.000,00 selisih Rp. 6.148.638.000,00 merupakan kerugian keuangan negara.

\section{Penutup}

Berdasarkan uraian di atas, disimpulkan: Pertama, faktor yang mempengaruhi kerugian keuangan negara dalam pengadaan alat kesehatan adalah faktor kemanfataan alat kesehatan sesuai kebutuhan dan faktor kewajaran harga. Apabila 
alat kesehatan dapat dimanfaatkan sesuai kebutuhan dengan harga yang wajar, maka tidak terjadi kerugian keuangan negara. Kerugian keuangan negara dalam pengadaan alat kesehatan terjadi apabila (a) alat kesehatan dapat dimanfaatkan sesuai kebutuhan dengan harga tidak wajar atau (b) alat kesehatan tidak dapat dimanfaatkan sesuai kebutuhan. Kedua, metode perhitungan kerugian keuangan negara dalam kegiatan pengadaan alat kesehatan dipengaruhi oleh sifat alat kesehatan dan kewajaran harga. Apabila sifat alat kesehatan merupakan suatu kesatuan agar dapat dimanfaatkan sesuai kebutuhan maka metode perhitungan kerugian keuangan negara yang digunakan adalah metode perhitungan total loss, namun apabila sifat alat kesehatan merupakan dapat dimanfaatkan secara terpisah maka perhitungan kerugian keuangan negara yang digunakan adalah metode kerugian bersih (net loss) yaitu jumlah pengeluaran dikurangi dengan nilai bersih alat kesehatan yang dianggap masih ada nilainya. Perhitungan kerugian keuangan negara dengan menggunakan metode kewajaran harga digunakan apabila alat kesehatan dapat dimanfaatkan sesuai kebutuhan dengan cara membandingkan harga wajar alat kesehatan berupa harga pasar setempat dibandingkan dengan realisasi pembayaran.

\section{Daftar Pustaka}

\section{Buku}

Republik Indonesia, Buku II Nota Keuangan Beserta Rancangan Anggaran Pendapatan Belanja Negara Tahun Anggaran 2019, Republik Indonesia, Jakarta, 2018.

Tuanakotta, Theodorus. M., Menghitung Kerugian Keuangan Negara dalam Tindak Pidana Korupsi, Salemba Empat, Jakarta, 2009.

\section{Hasil Penelitian/Tugas Akhir}

Direktorat Penelitian dan Pengembangan, Kajian Pencegahan Korupsi Pada Pengadaan Barang dan Jasa Pemerintah, Kajian, Komisi Pemberantasan Korupsi (KPK) Republik Indonesia, Jakarta, 2014

\section{Jurnal}

Agbiboa, Daniel Egiegba, "Between Corruption and Development: The Political Economy of State Robbery in Nigeria", Journal of Business Ethics, Vol. 108 No. 3, 2012. 
Ali, Mahrus, “Hubungan Antara Sumber dan Metode Penghitungan Kerugian Keuangan Negara dengan Penetapan Uang Pengganti", Jurnal Ius Quia Iustum, No. 1 Vol. 21, 2014.

Anisah, S. dan Trisno Raharjo, "Batasan Melawan Hukum dalam Perdata dan Pidana Pada Kasus Persekongkolan Tender", Jurnal Ius Quia Iustum, Vol. 25 No. 1, 2018.

Atmadja, A.P. Edi, "Penyelesaian Kerugian Daerah Melalui Penyetoran Ke Kas Negara: Suatu Kajian Hukum Doktrinal", Jurnal Tata Kelola \& Akuntabilitas Keuangan Negara, Vol. 3 No. 2, 2017.

Listiyanto, Apri, "Pembaharuan Regulasi Pengadaan Barang dan Jasa Pemerintah", Jurnal Rechts Vinding, Vol. 1 No. 1, 2012.

Paeh, Karel Antonius, "Pengembalian Kerugian Keuangan Negara Berdasarkan Rekomendasi Badan Pemeriksa Keuangan (BPK) Hubungan Dengan Unsur Kerugian Negara Dalam Tindak Pidana Korupsi", Jurnal Kartalogis, Vol. 5 No. 2, 2017.

Prasetyo, Fadli dan Kukuh, "Politik Hukum di Bidang Ekonomi dan Pelembagaan Konsepsi Welfare State di dalam Undang-Undang Dasar 1945", Jurnal Konstitusi, Vol. 9 No. 3, 2012.

Sianturi, Ronald Hasudungan dan Ahmad Feri Tanjung, "Implementation Imprisonment Penalty as Subsidiary of Fine Penalty: Inconsistency of State Financial Losses", International Journal Of Environmental E Science Education, Vol. 17 No. 7, 2017.

\section{Makalah}

Prabowo, Agus, “Tantangan Penataan Dalam Iklim Pengadaan Barang/Jasa Pemerintah di Indonesia", Makalah pada Intenational Business Integrity Conference (IBIC) 2016, 17 November 2016.

\section{Internet}

“Trend Korupsi Kesehatan Periode 2010 - 2015", https:/ /antikorupsi.org/sites / default/files/files/Siaran\%20Pers/Tren\%20Korupsi\%20Kesehatan $\% 2020$ 17.pdf , diakses pada tanggal 7 Desember 2018.

\section{Peraturan Perundang-Undangan}

Undang-Undang Nomor 17 Tahun 2003 tentang Keuangan Negara, Lembaran Negara Republik Indonesia Tahun 2003 Nomor 47, Tambahan Lembaran Negara Nomor 4286.

Undang-Undang Nomor 1 Tahun 2004 tentang Perbendaharaan Negara, Lembaran Negara Republik Indonesia Tahun 2004, Tambahan Lebaran Negara RI Nomor 5.

Undang-Undang Nomor 18 Tahun 2016 tentang Anggaran Pendapatan dan Belanja Negara Tahun Anggaran 2017, Lembaran Negara Republik Indonesia Tahun 2016, Tambahan Lebaran Negara RI Nomor 240. 
Undang-Undang Nomor 15 Tahun 2017 tentang Anggaran Pendapatan dan Belanja Negara Tahun Anggaran 2018, Lembaran Negara Republik Indonesia Tahun 2017, Tambahan Lebaran Negara RI Nomor 233

Peraturan Presiden Nomor 16 Tahun 2018 tentang Pengadaan Barang/Jasa Pemerintah, Lembaran Negara Republik Indonesia Tahun 2018, Tambahan Lebaran Negara RI Nomor 33.

\section{Putusan Pengadilan}

Putusan Mahkamah Agung Republik Indonesia No. 363 K/PID.SUS/2016 mengenai Pengadaan Cathlab pada Rumah Sakit Stroke Nasional (RSSN) Bukit Tinggi Tahun Anggaran 2012 dengan terdakwa H. Mawardi.

Putusan Pengadilan Negeri Bandung No. 67/Pid.Sus-TPK/2016/PN.Bdg mengenai Perkara Tindak Pidana Korupsi Pengadaan pengadaan 17 (tujuh belas) jenis alat kesehatan pada Rumah Sakit Cibabat Kota Cimahi yang bersumber dari Bantuan APBD Propinsi Jawa Barat Tahun Anggaran 2011 dengan terdakwa dr. Endang Kesuma Wardani.

Putusan Pengadilan Negeri Jakarta Pusat No. 30/PID.SUS/TPK/2017/PNJKT.PST mengenai perkara tindak pidana korupsi pengadaan program peningkatan pelayanan kesehatan pengungsi korban bencana dan penanggulangan masalah kesehatan pada pusat penanggulangan masalah kesehatan Tahun 2005 dengan terdakwa Siti Fadilah Supari. 